«Keruen» scientific journal

M.O.Auezov Institute of Literature and Art

ISSN 2078-8134,

Volume 73, Number 4 (2021)

FTAMP 17.71 .01

https://doi.org/10.53871/2078-8134.2021.4-07

\author{
${ }^{1}$ Zh.A. Zhakupov, ${ }^{2}$ L.K. Meirambekova* ${ }^{*}{ }^{3}$ B.A. Abdykhanova, ${ }^{4}$ S.T. Beisembayeva \\ 1,2,4 L.N.Gumilyov Eurasian National University, \\ Nur-Sultan, Kazakhstan. \\ ${ }^{3}$ Shakarim State University of Semey, Semey, Kazakhstan. \\ E-mail: 12han.zhak58@gmail.com,21meyrambekova@mail.ru, ${ }^{3}$ abdychanovab@mail.ru, \\ 4b.saule2003@list.ru \\ ${ }^{1}$ Orcid: 0000-0002-8141-5501, ${ }^{2}$ Orcid:0000-0003-2159-4007, \\ ${ }^{3}$ Orcid:0000-0001-8076-2336, ${ }^{4}$ Orcid:0000-0001-8902-7688
}

\title{
Some peculiarities of the linguistic representation of time and space in Kazakh fairy tales and epic poems
}

\begin{abstract}
It comes as no surprise that study of folklore language is regarded as arelevant issue. As the phenomenon of national cognition is revealed by identifying the semantics of the language. And in the linguistic study, researching the genre features of folklore has the results similar to interdisciplinary research. Folklore genres are studied sufficientlyin the literary and folkloric studies, in both domestic philology and foreign philology. Recognition of human space takes an important place in the formation of their national mentality. The language representation of the spatial category is based on its sophisticated image in human comprehension. Moreover, in the linguistic context, different types of spaces are mixed. Particularly, real, perceptual, conceptual, physical, geometric, geographical, astronomical and space, absolute and relative, free, abstract, anthropological-topical, social, mythological, artistic, etc. While studying the spatial category in folklore, it is important to first define the language units, which are the basis of the lexicon of the spherical language and the basis of space as a category of folklore language. The linguistic representation of time and space in Kazakh fairy tales and epic poems are considered in the given article. The characteristic features of the linguistic representation of time and space in Kazakh fairy tales and epic poems are analyzed. Moreover, relevant examples are offered as evidence. The relevance of the study is determined by great interest of linguistic science to the issues of national and cultural specificity of folk texts, which is caused by peculiarities of historical development, beliefs, traditions and customs of native people.
\end{abstract}

Key words: time, space, linguistic representation, fairy-tale, epic poems.

Introduction. The study of folklore language helps to reveal modern national language codes. For this purpose, it is necessary to analyze semantic and structural evidence in the texts of folklore genres and to show their linguistic features. To achieve this goal, the following specific scientific tasks must be fulfilled: assessment of genre classification of folklore texts; comprehensive study of folklore genres, determining their linguistic and national-spiritual values. By performing these tasks we can define the linguistic phenomena in folklore genres, artistic, cognitive, and cultural features of the folklore language, universal phenomena and individuality in folklore language. Such phenomena include the representation of time and space (Zhakupov, 2020: $523)$.

The category of space has attracted the attention of both domestic and foreign linguists for many years. At the same time, the interest of researchers to the problem of linguistic realization of the category of space is preserved in works of artin modern linguistics.It should be noted that the 
names of the most authoritative scientists who studied the category of space and its role in the structure of literary texts are such as Yu. M. Lotman (2), M.M. Bakhtin (3), N.D.Arutyunova (4), V.N.Toporov (5) and others. The category of space, being an ontological, conceptual and semantic category, is regarded as an object of comprehension, the results of which have a linguistic reflection. Space can also be perceived as «a set of objects between which relationships are established, similar in structure to ordinary spatial relationships such as neighborhood, distance, etc» (Lotman, 1996: 983). V. I. Toporov notes that space «forms a set, understood as a text (that is, space as such can be understood as a message» (Toporov, 1988: 227). Thus, space, being one of the fundamental textual categories, requires a more in-depth approach to the study of the ways of its representation in language, since «in the process of cognition and display of the surrounding world by linguistic means, space has an important, if not exclusive role» (Bakhtin, 975:154).

In his work «Forms of time and chronotope in the novel» M.M. Bakhtin gave the term a conceptual foundation. Each piece of art has its own individual time-space. It was this that was first pointed out by M.M. Bakhtin, enriching literary criticism with the term «artistic chronotope» (chromos - time, topus - space) and defining it as «an essential interconnection of temporal and spatial relations, artistically mastered in literature ...» (Bakhtin 1975:3). The scientist noted that «this term is used in mathematical natural science and was introduced and substantiated on the basis of the theory of relativity (Einstein)» (Bakhtin 1975:3).

The scientist assigns a special role to time, considering it the leading chronotope in literature, and characterizes it as the fourth dimension of space. (Bakhtin 1979: 121). According to M.M. Bakhtin, signs of time are revealed in space, and space is comprehended and measured by time (Bakhtin 1979: 177). Then the concept of a chronotope has been actively investigated in various fields of science. In social psychology, the term «chronotope» was defined as a communicative situation that tends to repeat itself in a certain place and at a certain time. And the scientist described the process of their interaction as follows: «In the literary and artistic chronotope, there is a fusion of spatial and temporal signs in a meaningful and concrete whole. Time here thickens, becomes denser, mature artistically, space is intensified, drawn into the movement of time, plot, history» (Bakhtin 1975: 141). According to the anthropocentric concept of the space of the literary text of M.M. Bakhtin, the text reflects a twofold image of the world and man: 1) the world is depicted outside - as the environment of a person and 2) the world is depicted from the inside - as a person's outlook (Bakhtin 1979: 121).

Research methods. The study of folklore genres language was conducted in a complex approach. This complex approach includes descriptive, comparative-historical, historicalcomparative, contrastive, diachronic-synchronous, lingual and cultural and cognitive methods. According to the principle of science studies, novelty is always based on the combination of sciences or various spheres, and with the use of a complex approach, new results have been obtained by linking linguistics and folklore. Our work can be based on ten volumes of the 100volume series «Babalar sozi» and the poem «Qozy Korpesh - Bayan Sulu».

Discussion and results. Fictional space may be unusually wide, cover the whole world (space in the science fiction); in the other hand, it can contract to the size of a room. In any case, however, the fictional space has certain structure: it has limits and connection with plotlines and groups of characters.

Space, the domain of settings and surroundings of events, characters and objects in literary narrative, along with other domains (story, time, character and ideology), constitutes a fictional universe. For the purpose of describing some features, of fictional spaces, we may assume that space is a semantic construct built with linguistic structures employed by the literary text. Yet, this distinction is based on the assumption that the components of the fictional space cannot be defined with specific textual expressions; rather, fictional constructs of space are the products of integration of dynamic bodies of spatial information. Thus, we can intend, more specifically, to describe the relations between various categories of space - constructs and their surface (linguistic) manifestations. 
A fictional text being a fictitious narrative (though it resembles the reality), gives the author an opportunity for free depiction of the passing time and creation in such a way different notional and stylistic effects.

Real time passes in one direction - from the past to the future that creates an irreversible coordinated sequence of events. In fictional texts chronological sequence may be broken. Often, in order to draw the reader's attention the author starts his narration from the middle, and then gives the exposition. Sometimes, especially in detective stories, the end of the chain of events works as the beginning of narration. Rearrangement of events sometimes may appear even in the factographic text (for example, in the adventures description), but only in case when such texts have the element of fictional depiction.

The uniformity of time is also broken in the fictional text. Usually, the speedup of time is used, its long distances are placed in the texts, which can be read from several minutes to several hours. The speedup of time is a distinctive feature of the ends of the long texts (novels); beginning with slow descriptions, the narration gathers speed, and events which takes years of life happen on several last pages. There is also slowing of time - detailed description of the events, for example landscapes, which are devoted to the same moment of time, though they are represented like a prosequence (Ruth Ronen, 1986:421).

It is known that the categories of time and space are philosophical and cognitive categories. Their linguistic representation leads to the linguistic space. One of the main categories of existence is the sequence and location of space objects in the global continuumand their relation to each other. The space is closely connected with time. Both are related to the matter. Nevertheless, they differ by their own qualities. Time lasts long, it does not repeat, and is irreversible. The space is stretching, with breaks and continuous. The spatial structure is determined by its objects location, be it high or low, if the objects in it coincide at a certain distance (1, p 523).

There are some peculiarities in the linguistic images of time and space in fairy tales. The space scope of fairy tales is immense, because space elements are located both horizontally (steppe, garden, palace, etc.) and vertically (cave, pit, sky, etc.). These linguistic units are constantly repeated in every single fairy tale with no change. Thus, a fairy-tale creates a group of linguistic units used in the space chronotope of the text. In folklore the space names often include words which mean generality and indefiniteness, rather than solitude and definiteness. It is formed by combination of space-meaning words with one indefinite pronoun: one big house, one belt, one pit, one side, one river and so on. For instance: Mergen syǵalap qarap tyrsa, qatyn ayańdap bir beldi asyp ketti. Oilady: "Munyń erkegi bar shygar, bir zhaqtan kelip qalar!» - dep atyna minip zhúrip ketti - literally.

While a rifleman was spying upon, a woman walked slowly and crossed one belt. He thought: "She might have a man, he might arrive all of a sudden from somewhere!» and then he sat in the saddle and continued his journey on horse. (BS. 74, 10).

Among the words that indicate directions in space, there is onepeculiarity, presented in the example: Osy aǵash zhanynda ush zhol bar: ońǵa, solǵa, tura. Oń zhaqtaǵy zholǵa tússeń, atty bolsa aty óledi, ózi salamat kalady. Aǵashtan sol zhaqqa ketse, ol kisi ólip, aty qalar. ... aǵashtan oń zhaqqa qaraǵan zholǵa túsip zhúrip ketken - literally.

There are three roads near the tree: right, left, straight. If you go on the right,_If he is on a horse, the horse will die, but he will remain alive. If he goes from a tree to the left, he will die and his horse will remain alive. ... he followed the road to the right of the tree (BS. 74, 27). In the given example, the fairy-tale reality denotes the perception of the world by the mythical world and the traditional culture through the ancient archaic periods, as the hero chooses the right road (In Kazakh «right way» also means lucky).

In accordance with the folk tradition and other genres of Kazakh folklore, there were classes of «mine» and «someone's» and it comes to the forefront of fairy tales. Detonates of space in fairy tales or myths are splitted into notions of «own» and «alien» can be observed through movements of a hero in tales. As example, lexems land, surface of the earth are treated as mine or own, while underneath, sky and water can imply «alien» or «others». To differentiate «own» or «alien» 
meaning of space -denoting units, context plays significant role. For example: ... iisi zhupar qalampyr sasyp turgan bir zhaqsy zhazira eken. (BS. 74, 9). Sometimes an unfamiliar world, characterized by exceptional beauty might fascinate a character and contributes to the perception of the world «not of someone else's», but of «his own». It can serve as a sign that alien space presented in fairy tales is not always ugly and frightening. "Zhazira» is a lexeme, acquiring positive meaning in Kazakh culture.But it is predictable that a comfortable zhazira space can cause a threat also. Because in the semantic structure of the fictional fairy tale there are many dangers, and many obstacles occur in such pleasant, impressive display locations. One example that springs to my mind is the fairy-tale "Qaramergen» the one of the «negative character» in the form of a woman; she will come at night to kill the shooter in one of the best region (BS. 74, 10).

In fictional fairy tales the event will develop in a definite closed space,because the main character returns to his destination (home, country) after a while.

For example: Uiine kelip, atqan ańnyń terisin, muizin satyp burynǵydan on ese paida kórdi - literally.

Having sold the skin and horns of the killed animal, gained ten times more profit, he came home (BS. 74, 12). The home lexeme, which is considered to be «my own», is not only the place where a person lives, but also the center of his world, a closed space, a space that protects him. The world outside the home is considered as «someone else», as a danger, various obstacles for the character begin after he leaves the house.The hero's way is directed to the sacred space center of the mythopoetic, religious model of the world, that is, movement has a beginning and an end.And the end point in the space - the most important, strongest zone, because it can only be achieved by overcoming obstacles. At the end point, the most valuable actions take place, a danger passes and good conquers evil, the main character becomes a hero and achieves the whole goal.

An exceptional linguistic presentation in epic poems of time and space is as follows. In the Kazakh epos, as in others, «the past tense is interspersed ... with the present», because «the singer does not make a fundamental difference between the narrative and the description, the narration is interpreted as a description. Time expresses not only time, but also space relationships. Thanks to the application of the present, events related to the past are transferred to the space that is scattered in front of the listener's mental gaze in the present (Propp, 199: 538)». Time forming a predicate in sentences of heroic poems, D. S. Likhachev supposed to call the past conditional era as the «epic era: "The artistic time of the main genres of folklore is always closed. It is closed even in the improvisations of cries. It begins with the beginning of the work and ends in it. In a lyric song, a fairy tale and epics, it is not strictly defined in historical time. Due to the closed of time, it is able to «repeat» in execution. Each of the folklore works of these genres seeks to bring the time of events closer to the time of performance. This is possible due to the conventionality of the first and the artificial extension (in conditional limits) of the second: slowing down the narrative to convey the narrative slowness»), - he wrote. One of the phenomenological functions of the category of syntactic predicates in the texts of Kazakh epic poetry is that it not only shows grammatical tenses, but it can be assumed that it describes an epic era (Likhachev, 1979: 246).

For instance, In this passage, the present also expresses the past tense: Toptanyp turgan kápirge Qobylandy jalǵyz tıedi, Bólingen qoudal qyrady. Jalǵyz ózi batyryń Jolyp ketip barady. Qoiǵa tıgen qasqyrdal Solyp ketip barady. Jolbarys shapqan qulandal, Jolyp ketip barady literally.

Beating them down like sheep

He leaves alone defeating the enemy

He defeats the enemy as a wolf deals with a sheep

He copes with the enemy like a tiger attacking a kulan

With a crowd of godless Koblandy is fighting alone. (BS. 38, 79).

And in the next passage, the past tense is regarded as present situation both from the story teller's and the recipient's sides:

sapty súngimen Yrǵal, yrǵal salysty,

Qylyshtasyp ekeýi Qarsylasyp shabysty. 
Iterisip turysty,

At tizesin búgisti,

Búge-búge turysty - literally.

They rushed at each other with peaks with wooden handles

attacked each other on horses with sabers,

fought each other all the way (until the horses knelt) (BS, 38, 74).

The time category is shown in two waysin historical poems. Firstly, historical epoch depicted in historic poems is associated with historical reality. Historical reality in the poem is regarded as a manifestation of objective time. The historical reality in poems is reflected in entire stages of the history of the Kazakh people and the image of famous people who lived in that era. The content of the work develops on the basis of a historical event or figures. The content of historical poems is regarded as historical events, historical figures of that time. There are also other aspects of the time category in historical poems. It is perceptual time. That is, the people's perception and convey of the historical event depicted in historical poems. The purpose of historical poems is not only to describe a particular historical event,convey its historical significance and essence.People transmitting a certain historical fact, show the contradictions inherent in that era and evaluates the historic personality. On the basis of this, it is possible to change the plot of historical facts and to combine with artistic thoughts. The historical consciousness of the people of that time is clearly displayed. For example, in the historical poem «Abylai Khan» through the trops that describe Abylai Khan, historical time and space are represented: Abyla elge bitken bir bátterek - Abylai is like an oak, protecting the people (figuratively baitetek means protection or support - Abylai is regarded as a protection for his land) (BS. 29, 140), Halqyna asqar taýda1 bolǵan tirek.

Elge boldyń bir shyraq, You became for your people as a light

Aqylyń darıa, bir bulaq, Your mind is as wide as river.

Aqyldyń bitip jatqan kózin ashty You cleared the source of mind hooded. (BS. 29, 138),

Astynda ashyq aspan saǵym salǵan, In the open air created a dream

Aidyn kól alabynan munar shalǵan. Built a palace on the water surface of the lake (BS. 29, 135).

There is an idealism between the heroic epic and the historical epic. However, there are some differences in the linguistic representation of the time category. In both actions are reflected in the past, but in the heroic epic there will be an unreal time (as evidenced by the fact that the verbs are presented in the form of the past tense - ypty, -ipti), in the historical epic there will be a real time (this is because the verbs are given in the past, in the form -gan, -gen, -qan, -ken).

In historical poems at the interface of objective time and perceptual time the stream of past history of the people and the current assessment of the people are reflected. That is why Kazakh historical poems differ from other folklore genres in content, composition and narration.

One of the genres of folklore - in the lyric-epic poems, the system of space relations is represented by various linguistic units.

In particular, the basic unit of the local relation in the language, that is, nouns and auxiliary parts of speech, geographical names, addresses, adverbs with space mean are often used as space means. For example:

Qasynda qyryq qyz bar qyzmetkeri,

Qyzdar turyp aldyna jar-jar altyp;

Keldi de patsha aldyna jaýap berdi.

Han tysta ashý qylyp aqyrady,

Kóp ásker bári endi ortaǵa aldy.

Kóp ishinde neqylsyn,

Han qasynda otyrǵan Bller menen aǵadan;

Sen aldym da bolmasań,

Bu dúnieni ne etermin? -literally (BS. 17-volume, «Bozzhigit»). 
has forty girls servants nearby,

girls standing in front sang a song

came and before the khan gave an answer

outside the khan growled of anger

A huge army is now around them

what will he do withthose people

next to Khan, Bii and the elders,

why do I need this world

if you are not nearby

In the given example, qasynda, aldynatysta, ortaǵa andishinde are linguistic indicators of space communication characterizing movement and location of the subject within a certain space.

The category of space in the epic is distinctly manifested in description of the name of places or events. For example, Garshy menen Kúrsini, Laýh penen Qalamdy, On segiz myń galamdy Alty kúnde jaratyp Bende qylǵan Alamsyń (BS. 17, 28). Shár - Býstan Rumnan Bizdi izdeseń, tabarsyń. Býstan shárdiń bulbuly. - literally (BS. 17, 33).

You are the God, who created Garshy and Kursyn, Laukh and Kalam, who created in six days 18 thousand worlds (figuratively - the whole earth with all living and nonliving creatures). You will find us in Bustan and Rome if you in search for us, nightingale of Bustan (BS. 17, 33).

In their poems, linguistic units denoting natural objects of open space, on the one hand, refer to the nature of the object defined by it, on the other hand, are related to their meaning in the folklore language. For example:

Darıa keship,

ótseń, Bizdi izdeseń, tabarsyń (BS. 17, 33).

Kúnmenen tún bular júrdi deıdi,

Shárden-shárge bular júrdi deidi.

Ár jerde shár kózge kórinse,

At basyn oǵan qarap burdy deidi (BS. 17, 38).

Qyrdaǵy kóp shárden jaryn tappa1,

Darıamen keme qylyp ketti deıdi.

Bar eken bir araldamımýn shár,

Qudaıym oǵan túserge etti deıdi (BS. 17, 33).

Taýdan, tastan, darıdan ótti (BS. 17, 43).

Bir kósheniń ishinde júrip edi,

Qyryq qyz bosyp jatyr, kórdi deldi (BS. 17, 44).

Bir saraıdyń ishinde ot janady,

Kóp qyzdar úı ishinde sóılep jatyr-literally .

passing the river, passing the mountains, you will find us

day and night they walked

they went from city to city

wherever they saw the city, turned their horses there

Not finding his soul mate in many cities

He sailed on the ship in the seas

there is the city of Mimun on the island of one

God sent him a sign

Passed through mountains, passes and rivers

On one of the streets forty girls he saw escaping

A fire was burning in the palace

Inside the house, the girls were speaking...

Natural objects (mountain, land, canyon, island, stone) are represented in the open space by artificial objects (street, shed, house, etc.). Linguistic units describing natural objects help to determine the extent of space category in folklore. 
It is known that linguistic features denoting spaces are constantly changing depending on the plot of the work. Such changes are also depicted in the poem «Bozzhigit». For example:

Joq shyǵar bujalǵanda muńsyz týǵan - There is no person in the world, who was born without sorrow,

Dúnıege adam uly qonaq bolǵan (BS. 17, 27) - a man came as a guest to this world jalǵyz da óter dúnıeden (BS. 17, 78)- he will go to another world lonely

Az ómirde parda joq, Ujmaq bolsyn ornyńyz (BS. 17, 114) - there is no benefit from a short life, let your place be paradise

Qara jerge kirgenshe - while you go to black earth

Jaman joldan qalmaisyń - have to go on a bad road

Janǵan ottyń ishinde - inside fiery hell

Ujmaq taman bararsyń (BS. 17, 115) - Come to paradise

Molasynda zar enirep turdy deıdi - they say he cried loudly in the grave

Segiz qabat ujmaqty- eight layers of paradise

Jeti qabat tamuqty (BS. 17, 29) - seven layers of hell.

The highlighted units in the given excerptions are linguistic units that form the lexical layer «life-death» space category.

To the explicit representation of time and space in the linguistic image of the world in the Kazakh lyric-epic works, the following facts from the text «sad-Zarlyk» can be cited:

Alpys kún júrgen jolyna, on bes kúnde keledi, On a journey of 60 days, he spent 15 days

On jylǵa shein qarady - looked after 10 years

On jyl tamam ótkenshe (BS. 52,11) - 10 years have passed

Dál otyz kún bolǵanda (BS. 52, 34) - exactly 30 days have passed

Toqsan kúndik joly bar arasynyń (BS. 52,31) - 90 days have passed in travel

...kólden kóldi qydyryp» (BS. 52, 14) - traveled through the seas

Altynshy taýdan ary asyp, Jetinshi taýǵa jáne asyp - going through the sixth mountain, only reached the seventh mountain

«Túlki ketpes túleiden, Túnde ketip barady»,

«It tatpaǵan ashshy kól, Ashy kól men tushshy kól, Budan ótip barady» -the salty sea that even dog will not drink, bitter lake and salt lake

«Júrgeni japan túz boldy» (BS. 52, 33) - the place where he travelled by was desert.

In all genres of folklore, time and space are closely related, but the certain breaks may occur in space events. This is also characteristic of «time» scale in the poem «Qozy Korpesh - Bayan Sulu». For example: Buryngy nogailynyn zamanynda In the past era of Nogai... (БС. 26, 9); Eline qaityp bargan kezderinde When you go back to your country,...(БС. 26, 14); Akem tiri kuninde aitturypty, Tusimde ayan etti ata-babam When my father is alive, In a dream my ancestors gave a vision (BS. 26, 17); Zhasynan zhetim qalgan munyn aitty An orphan from an early age talked about his grief (BS. 26, 22); Zheti zhastan sharqaya atangan son,... When I exceeded my seven-year old age. (BS. 26, 29). The linguistic units, separated by black here, describe an event that happened some time ago, thereby show the gap between the time meaning and the time between narrated events.

When analyzing linguistic data in the poem, it was found that lexemes in the «time» field are divided into several microfields. For example, microfield lexeme «sun»: in one day, at my young age, three days etc.; microfield lexeme «year»: ten years, how many years, for ten years etc.

According to the linguistic data taken from the poem «Qozy Korpesh - the «time» field in the poem is closely related in content, consists of many homogeneous (twenty-four hours hyponnight, day, lunch, evening т.б.; month hypon - May, June; seasons - winter, spring, summer, autumn and etc.) and diverse (word, word collocation, etc.) linguistic units of mutual relations that determine the meaning of each other.

The concept of space in the genres of folklore is a common concept - «earth-water». The semantic range is as follows: the concept of unifying the universe (higher - God, down - Umai, 
middle - Human); an opposition of high and low worlds,god,worshiped by creatures, but not a god, a world in which humanity lives, a part of space; notion of Homeland, where a person is born,ancient names for the concept of Fatherland; nature itself, i.e. geographical objects; signs reflecting time and space correlations which are saved by the humanity from the ancient times. evidences of historical notions, recognized by folklore plots thanks to toponyms; a complex set of views and ideas on world and space presented in marks and symbols. This core of the concept sphere (axis, center) can be seen in one example:

Ákeń seniń - qara jer, Shesheń seniń - qara jer, Barar jeriń - qara jer, Turar jeriń - qara jerliterally

Your father is the black earth, Your mother is the black earth, your last home will be black earth, the place where you live is the black earth (BS. 17, 105)

Conclusion. One of the main categories of existence is the sequence and location of space objects in the global continuumand their relation to each other. The space is closely connected with time. Both are related to the matter. Nevertheless, they differ by their own qualities. Time lasts long, it does not repeat, and is irreversible.The space is stretching, with breaks and continuous. The spatial structure is determined by its objects location, be it high or low, if the objects in it coincide at a certain distance. What is proved with the relevant examples which are taken mostly from the ten volumes of the 100 -volume series «Babalar sozi» and the poem «Qozy Korpesh - Bayan Sulu».

Event in Kazakh fairy tales has its beginning and end,which is stated in a confined space and time, forms the semantic structure of the whole text. In fictional fairy tales among linguistic units denoting time and space, words and phrases that have turned into folk tradition are also detected.

Taking into account what have mentioned above the national codes of the Kazakh folklore will be disclosed on the language representation of time and space. There is some evidence to support that this is a phenomenon of folklore.

\footnotetext{
${ }^{1}$ Ж.А.Жақыпов, ${ }^{2}$ Л.К.Мейрамбекова ${ }^{3}$ Б.А. Абдыханова,${ }^{4}$ С.Т.Бейсембаева

1,2,4 Л.Н. Гумилев атындағы Еуразия ұлттық университеті, Нұр-Сұлтан, Қазақстан.

${ }^{3}$ Шәкәрім атындағы мемлекеттік университеті, Семей қаласы, Қазақстан,

E-mail: 1'zhan.zhak58@gmail.com,21meyrambekova@mail.ru,

3abdychanovab@mail.ru, ${ }^{4} b$. saule2003@list.ru

Orcid: 0000-0002-8141-5501, Orcid: 0000-0003-2159-4007,

Orcid: 0000-0001-8076-2336, Orcid: 0000-0001-8902-7688
}

\section{Қазақ ертегілері мен эпостық жырларындағы уақыт пен кеңістікті тілдік бейнелеудің кейбір ерекшеліктері}

Андатпа. Фольлордың тілін зерттеу - актуалды міндет. Өйткені бұл тілдің семантикасын анықтау арқылы ұлттық танымның феномендік сипаттары ашылады. Ал лингвистикалық зерттеуде фольклордың жанрлық ерекшеліктерін есепке алу пәнаралық зерттеулерге тән нәтижелер береді. Фольклор жанрларын әдебиеттанулықфольклортанулық тұрғыдан зерттеу отандық филологияда да, шетелдік филологияда молынан зерттелген. Адамның кеңістікті тануы оның ұлттық менталитетінің қалыптасуында маңызды орын алады. Кеңістік санатының тілдік репрезентациясы оның адам танымындағы күрделі бейнесіне негізделеді. Оның үстіне тілдік түсінікте кеңістіктің әртүрлі типтері араласып отырады. Атап айтқанда, реалды, перцептуалды, концептуалды, физикалық, геометриялық, географиялық, астрономиялық және ғарыштық, абсолютті және қатыстық, бос, абстрактілі, антропоөзектік, әлеуметтік, мифологиялық, көркем т.б. Кеңістік санатының фольклордағы болмысын зерттеу барысында, алдымен, фольклор тіліндегі кеңістік санатының лексикасы мен кеңістіктің санат ретінде қалыптасуына негіз болатын тілдік бірліктерді анықтау аса маңызды. Бұл мақалада қазақ ертегілері мен эпостық 
өлеңдеріндегі уақыт пен кеңістіктің тілдік бейнесі қарастырылады. Қазақ ертегілері мен эпостық жырларында уақыт пен кеңістікті тілдік бейнелеудің сипаттамалық ерекшеліктері талданады. Сонымен қатар, дәлел ретінде тиісті мысалдар келтірілген. Зерттеудің өзектілігі лингвистикалық ғылымның халық мәтіндерінің ұлттық-мәдени ерекшелігі мәселелеріне үлкен қызығушылығымен байланыстырылады, яғни бұл тарихи даму ерекшеліктерінен, сенімдерінен, халқының дәстүрлері мен әдет -ғұрыптарынан туындайды.

Түйін сөздер: уақыт, кеңістік, тілдік бейнелеу, ертегі, эпос.

\author{
${ }^{1}$ Ж.А. Жакупов, ${ }^{2}$ Л.К. Мейрамбекова ${ }^{*}{ }^{3}$ Б.А. Абдыханова,${ }^{4}$ С.Т. Бейсембаева \\ 1,2,4 Евразийский национальный университет имени Л.Н. Гумилева, \\ Нур-Султан, Казахстан. \\ ${ }^{3}$ Государственный университет имени Шакарима города Семей, \\ Семей, Казахстан, \\ E-mail: 1'zhan.zhak58@gmail.com,21meyrambekova@mail.ru, \\ 3abdychanovab@mail.ru, ${ }^{4}$ b.saule2003@list.ru \\ Orcid: 0000-0002-8141-5501, ${ }^{2}$ Orcid: 0000-0003-2159-4007, \\ ${ }^{3}$ Orcid: 0000-0001-8076-2336, ${ }^{4}$ Orcid: 0000-0001-8902-7688
}

\title{
Некоторые особенности языковой репрезентации времени и пространства в казахских сказках и эпических поэмах
}

Аннотация. Неудивительно, что изучение фольклорного языка считается актуальной проблемой, так как феномен национального познания раскрывается путем выявления семантики языка. А в лингвистическом исследовании изучение жанровых особенностей фольклора имеет результаты, аналогичные междисциплинарным исследованиям. Фольклорные жанры достаточно изучены в литературоведении и фольклористике, как в отечественной, так и в зарубежной филологии. Осознание человеком пространства играет важную роль в формировании его национального менталитета. Лингвистическая репрезентация пространственной категории основана на ее сложном образе в человеческом познании. Более того, в языковом понятии смешаны разные типы пространства. В частности, реальное, перцептивное, концептуальное, физическое, геометрическое, географическое, астрономическое и космическое, абсолютное и относительное, свободное, абстрактное, антропоцентрическое, социальное, мифологическое, художественное и т. д. Изучая природу категории пространства в фольклоре, важно сначала определить лексику категории пространства в языке фольклора и языковые единицы, которые составляют основу для формирования пространства как категории. В данной статье рассматривается языковая репрезентация времени и пространства в казахских сказках и эпических поэмах. Анализируются характерные особенности языковой репрезентации времени и пространства в казахских сказках и эпических поэмах. Более того, в качестве доказательства предлагаются соответствующие примеры. Актуальность исследования определяется большим интересом лингвистической науки к вопросам национально-культурной специфики народных текстов, что обусловлено особенностями исторического развития, верованиями, традициями и обычаями коренных народов.

Ключевые слова: время, пространство, лингвистическая репрезентация, сказка, эпос.

\section{Свидение об авторе:}

Жакупов Жантас Алтаевич -Доктор филологических наук, професор, Евразийский национальный университет имени Л.Н. Гумилева, город Нур-Султан, Казахстан. zhan.zhak58@gmail.com, Orcid ID0000-0002-8141-5501 
Мейрамбекова Лязат Касымовна - PhD, и.о.доцента, Евразийский национальный университет имени Л.Н. Гумилева, город Нур-Султан, Казахстан. Imeyrambekova@mail.ru, Orcid ID 0000-0003-2159-4007

Абдыханова Бактыгул Айдапкелевна- PhD, и.о.дочента, Государственный университет имени Шакарима города Семей, Семей, Казахстан. abdychanovab@mail.ru. Orcid ID 0000-0001-8076-2336

Бейсембаева Сауле Толеутаевна- Кандидат филологических наук, и.о.доцента, Евразийский национальный университет имени Л.Н. Гумилева, город Нур-Султан, Казахстан.b.saule2003@list.ru. Orcid ID0000-0001-8902-7688

\section{References}

[1] Arutyunova N.D. Human language and world. - Moscow, 1999. - 896 p.

[2] Bakhtin M.M. Forms of time and chronotope in the novel. Essays on Historical Poetics // Issues of Literature and Aesthetics. - Moscow: Artist literature, 1975 P. 234-407.

[3] Bakhtin M.M. Time and space in the works of Goethe // Bakhtin M.M. Aesthetics of verbal creativity. - Moscow, 1979.

[4] Likhachev, D.S. Poetics of Old Russian Literature. - 3rd ed.-Moscow: «Science», 1979.

[5] Lotman Yu.M. Analysis of the poetic text. - St. Petersburg: Art-St. Petersburg, 1996. $846 \mathrm{p}$.

[6] Propp V.Ya. Russian heroic epic. (Collected works of V. Ya. Propp.) Commenting article by N. A. Krinichnaya. Compilation, scientific edition, index S.P. Bushkevich. - Publishing house «Labyrint». - Moscow, 1999.

[7] Ruth Ronen. Space in fiction. Poetics and comperative literature. Volume 7:3. Published By: Duke University Press. 1986. 421-438 p.

[8] Toporov V.N. Space // Myths of the peoples of the world. Encyclopedia in 2 volumes. V.2. - Moscow: Soviet encyclopedia. 1988. - P. 340-3426.

[9] Zhakupov Zh., Meirambekova L.K., Aimukhambet Zh., Akhmetova M., Yespekova L., Syzdykova G. Linguistic representation of time and space in Kazakh folklore genres. Opcion. Año - Venezuela. - 2020. - №36, Num. 91. - P. 523-535.

\section{Әдебиет:}

[1] Арутюнова Н.Д. Адамзат тілі және әлемі. - Мәскеу, 1999. - 896 б.

[2] Бахтин М.M. Гете шығармаларындағы уақыт пен кеңістік // М.М. Бахтин Сөздік шығармашылық эстетикасы. - Мәскеу. 1979.

[3] Бахтин M.M. Романдағы уақыт пен хронотоптың формалары. Тарихи поэтика очерктері // Әдебиет және эстетика мәселелері. Мәскеу: Көркем әдебиет. 1975 Р. 234-407.

[4] Жақыпов Ж.А., Мейрамбекова Л., Аймұхамбет Ж.Ә., Ахметова М.К., Еспекова Л.Ә., Сыздықова Г.О. Қазақ фольклоры жанрларындағы уақыт пен кеңістіктің тілдік репрезентациясы. Opcion. Año - Venezuela. -2020. - №36, №91. - Б. 523-535.

[5] Лихачев Д. С. Ежелгі орыс әдебиетінің поэтикасы. - 3-ші басылым. - Мәскеу: Ғылым. 1979.

[6] Лотман Ю.М. Поэтикалық мәтінді талдауы. - Санкт-Петербург: Өнер-СанктПетербург, 1996. - 846 б.

[7] Пропп В.Я. Орыстың қаһармандық эпопеясы. (В.Я. Пропп шығармаларының жинағы) Н.А.Криничнаяның түсіндірме мақаласы. Құрастыру, ғылыми басылым, индекс С. П. Бушкевич. - Мәскеу: Лабиринт, 1999.

[9] Рут Ронен. Көркем әдебиеттегі кеңістік. Поэтика және салыстырмалы әдебиет. Duke University Press, 1986. - Т.7:3. - 421-438 бб.

[9] Топоров В.Н. Ғарыш // Дүние жүзі халықтарының мифтері. 2 томдық энциклопедия.- Мәскеу: Кеңес энциклопедиясы. 1988. - Т.2. - Б. 340-342 бб. 


\section{Литература:}

[1] Арутюнова Н.Д. Человеческий язык и мир. - Москва, 1999. - 896 с.

[2] Бахтин М.М. Время и пространство в творчестве Гете // Бахтин М.М. Эстетика словесного творчества. - Москва, 1979.

[3] Бахтин М.М. Формы времени и хронотоп в романе. Очерки исторической поэтики // Вопросы литературы и эстетики. -Москва: Художественная литература, 1975. Б.234-407.

[4] Жакыпов Ж.А., Мейрамбекова Л., Аймухамбет Ж.А., Ахметова М.К., Еспекова Л.А., Сыздыкова Г.О. Лингвистическая репрезентация времени и пространства в жанрах казахского фольклора. - Opcion. Año - Venezuela, 2020. - №36. - №91. - C.523-535.

[5] Лотман Ю.М. Анализ поэтического текста. - Санкт-Петербург: Исскуство-СанктПетербург, 1996. - 846 б.

[6] Лихачев Д.С. Поэтика древнерусской литературы. - 3-е изд. - Москва: Наука, 1979.

[7] Пропп В.Я. Русский героический эпос. (Собрание трудов В. Я. Проппа.) Комментирующая статья Н.А. Криничной. Составление, научная редакция, именной указатель С.П. Бушкевич. - Москва: Лабиринт, 1999.

[8] Рут Ронен. Космос в художественной литературе. Поэтика и сравнительная литература. Duke University Press, 1986. - Т.7:3. С.421-438.

[9] Топоров В.Н. Космос // Мифы народов мира. Энциклопедия в 2-х томах.- Москва: Советская энциклопедия. 1988. Т.2. - С. 340-342. 